\title{
Correction to: Transdermal Permeation of Caffeine Aided by Ionic Liquids: Potential for Enhanced Treatment of Cellulites
}

\author{
Audrey N. Hernandes, ${ }^{1}$ Rodrigo Boscariol, ${ }^{1}$ Victor M. Balcão, ${ }^{1,2}$ and Marta M. D. C. Vila ${ }^{1}$
}

published online 28 April 2021

A Correction to this paper has been published: https://doi.org/10.1208/s12249-021-02015-9

Correction to: AAPS PharmSciTech

https://doi.org/10.1208/s12249-021-01956-5

An English translation error occurred with the word usage of "cellulitis" in the title and throughout the article. The correct usage is "cellulite". The original article has been corrected.

Publisher's Note Springer Nature remains neutral with regard to jurisdictional claims in published maps and institutional affiliations.

${ }^{1}$ PhageLab - Laboratory of Biofilms and Bacteriophages, University of Sorocaba, Sorocaba, SP 18023-000, Brazil.

${ }^{2}$ To whom correspondence should be addressed. (e-mail: victor.balcao@prof.uniso.br) 